(1982). Objectivity and commitment in linguistic science: The case of the Black English trial in Ann Arbor. Language in Society 11(2):165-201.

— \& Bettina Baker (2015). African American Vernacular English and reading. In Lanehart (ed.), 616-36.

Lanehart, Sonja L. (ed.) (2015). The Oxford handbook of African American Language. New York: Oxford University Press.

Newkirk-Turner, Brandi, \& Lisa Green (2016). Third person singular -s and event marking in child African American English. Linguistic Variation 16(1):103-30.

Reaser, Jeffrey; Carolyn Adger; Walt Wolfram; \& Donna Christian (2017). Dialects at school: Educating linguistically diverse students. New York: Routledge.

Terry, J. Michael; Evangelos Evangelou; Randall Hendrick; \& Richard L. Smith (2015). Dialect switching and mathematical reasoning tests: Implications for early educational achievement. In Lanehart (ed.), 637-58.

(Received 18 January 2018)

Address for correspondence:

William Labov

Department of Linguistics

3401-C Walnut Street Suite 300, C Wing

University of Pennsylvania Philadelphia, PA 19104-6228, USA

labov@comcast.net

Language in Society 47 (2018)

doi:10.1017/S0047404518000271

\title{
White affects and sociolinguistic activism
}

\author{
M A R Y B U C H O L T Z* \\ University of California, Santa Barbara, USA
}

This year, undergraduates in my class 'Language, race, and ethnicity' carried out collaborative sociolinguistic activism projects addressing a range of issues in our community, such as racist street signs and California's ban on diacritics in personal names on official documents. Despite my and my teaching assistants' explicit instructions that the projects should aim to effect some tangible change- - the replacement of the street signs, the legalization of diacritics - many students focused instead on the more amorphous goal of 'raising awareness' of these issues on our campus and in the local community. As we explained, while raising the public profile of a social injustice is a necessary step toward changing it, this act alone cannot bring about change. 
Yet I've come to realize that in my eagerness to show students and the general public the relevance of linguistics to social justice issues, I myself may have missed the mark. There's no question that language is a key basis for the perpetuation of social injustice, and particularly racial injustice, given that race and language are inextricably bound together (Flores \& Rosa 2015; Alim, Rickford, \& Ball 2016; Rosa \& Flores 2017). Understanding these processes is therefore an urgent task confronting sociocultural linguists. ${ }^{1}$ For example, the Santa Barbara street name Indio Muerto 'dead Indian' not only reflects a history of violence against indigenous Californians but also represents a form of ongoing linguistic violence that continues to harm the local Native community. But redressing linguistic inequality on its own cannot redress racial inequality. Even in the highly improbable event that language could be removed from racist projects, racism, ever resourceful, would simply find a new basis for social differentiation and political subordination. To put it bluntly, when Californians of Latinx heritage are being deported indiscriminately, does the name of the street where they used to live really matter, or whether diacritics were used in their names on the deportation orders?

Sociocultural linguists use the tools of linguistics to intervene in social issues because that's what we know how to do, not because those are necessarily the best tools for the job. We know how to uncover linguistic patterns, we know how to educate others about linguistic concepts and findings, but few of us received training in how to dismantle white supremacy or in how academia often unwittingly participates in the reproduction of racism. Mark Lewis' nuanced and constructive critique of William Labov's (1982) principle of error correction is therefore a much-needed wake-up call to the field: not just a call to action, but a call to critical reflection before leaping into action. He also demonstrates the necessity of using the insights of other fields to improve our own work.

Lewis rightly argues that Labov's principle is overly optimistic in its assumption that racism is driven by lack of knowledge and that remedying that lack will therefore eliminate racism. As he points out, Labov was by no means the first or only socially engaged scholar to misjudge Americans' receptiveness to antiracist arguments, and he was certainly not alone in prematurely celebrating the power of sociolinguistic expertise to eradicate racist educational policy. The federal legal case over educational inequality that was the impetus for Labov's formulation of his principle is frequently cited as a (rare) victory for sociolinguistics in public conflicts over racialized language. But Lewis reminds readers of Geneva Smitherman's (2004) important historical retrospective of the case, which notes that the victory was more apparent in the courtroom than in the classroom.

Lewis draws on critical race theory (CRT) in his discussion of the principle of error correction, a particularly appropriate framing since both CRT and Labov's principle emerged from an engagement with the legal system around issues of racial injustice. CRT calls attention to racism as a system for producing material inequality rather than as the result of uninformed or biased beliefs; it thus provides a crucial lens for understanding the material, structural stakes of raciolinguistic 
ideologies (see also Flores \& Chaparro 2017). As Lewis notes, however, the theory of materiality that CRT espouses excludes the forms of linguistic materiality that centrally concern sociocultural linguistics (Cavanaugh \& Shankar 2017). One kind of linguistic materiality of particular importance is affect.

Although affect may seem to be simply another manifestation of the idealist view of racism that Lewis rejects, I would argue, following researchers in multiple fields, that affects are not mere individual psychological experiences but social, material, political, and racialized phenomena that can uphold or challenge white supremacy (Ahmed 2004; Berg \& Ramos-Zayas 2015; Ioanide 2015). White affects wield guns, build walls, segregate cities, defund schools, redraw voting districts, and create racist educational policies (and racist street signs). Racism is fundamentally affective rather than rational, and thus it is not simply material self-interest that supports racism but the affective investment in whiteness (cf. Lipsitz 1998) that compels white people to cling to white supremacy at all costs.

As linguists we enter the affective battleground of racism equipped with our training in the weapons of modernity—rationality, empiricism, objectivity-yet racism resists these scientific logics. The liberal approach to sociolinguistic activism represented by the principle of error correction therefore fails not because it focuses on affects (or, more narrowly, 'attitudes') but because it tries to change affects with facts. Rather than coddling white affects and coaxing white people to see the sociolinguistic light, we need to use our research, teaching, and activism to expose white affects as the dangers they are to the well-being of people of color (DiAngelo 2011; Leonardo \& Zembylas 2013).

As Lewis rightly argues, in order to foster social justice, sociocultural linguistics must shift from a liberal perspective of benevolent scientific objectivity to a more politically engaged stance. However, his three valuable guiding questions to foster critical reflexivity among researchers, while valuable starting points, may overestimate the capacity of sociocultural linguists (myself very much included) to identify and interrogate the assumptions of our own work. A crucial additional component of this process of self-inquiry is suggested in the penultimate sentence of Lewis' article: 'the spirit of critical AND COLLABORATIVE reflexivity within sociolinguistics' (Lewis, this issue, p. 342, emphasis added). Social change requires collective action, and sociocultural linguists must collaborate within and across fields as well as beyond academia not only in conducting research, but also in the more difficult effort to critique our own and others' failures and limitations. It is only by being receptive and responsive to the critical insights of our colleagues, our students, and the communities we work with that we can move from social description to social critique to social change. And it is only by openly acknowledging the white supremacy of linguistics as a field and how our own individual racial subjectivities and affects shape our work that we can recognize and undo the racism that lies at the basis of our discipline. This is an undertaking in which white linguists have a great deal to learn from scholars of color, both within and beyond linguistics. 
In short, there's only so much we can do to challenge racism in our professional capacity as linguists, at least as the discipline is currently construed - although we can and must do much more than we've done so far. We need to learn from and make common cause with scholars, activists, and community members focused on the racist legacies of settler colonialism, chattel slavery, and genocide, including educational inequality, economic disparities, and state-sponsored violence. In today's postfact era, it is more imperative than ever that we go beyond 'raising awareness' to linking our expert knowledge with a deeper, more explicit political engagement. Our field is in debt to Mark Lewis for reminding us of this fundamental responsibility and for offering us guidance in how to meet it.

\section{N O T E S}

*My thanks to my graduate students in my Fall 2017 'Topics in sociocultural linguistics' course for their insightful comments; any remaining deficiencies are wholly mine.

${ }^{1}$ I use the term sociocultural linguistics as a broad cover term for the interdisciplinary field that includes sociolinguistics, linguistic anthropology, and other approaches (Bucholtz \& Hall 2008).

\section{R E F E R E N C E S}

Ahmed, Sara (2004). The cultural politics of emotion. Edinburgh: Edinburgh University Press.

Alim, H. Samy; John R. Rickford; \& Arnetha F. Ball (eds.) (2016). Raciolinguistics: How language shapes our ideas about race. Oxford: Oxford University Press.

Berg, Ulla D., \& Ana Y. Ramos-Zayas (2015). Racializing affect: A theoretical proposition. Current Anthropology 56(5):654-77.

Bucholtz, Mary, \& Kira Hall (2008). All of the above: New coalitions in sociocultural linguistics. Journal of Sociolinguistics 12(4):401-31.

Cavanaugh, Jillian R., \& Shalini Shankar (eds.) (2017). Language and materiality: Ethnographic and theoretical explorations. New York: Oxford University Press.

DiAngelo, Robin (2011). White fragility. International Journal of Critical Pedagogy 3(3):54-70.

Flores, Nelson, \& Sofía E. Chaparro (2017). What counts as language education policy? Developing a materialist anti-racist approach to language activism. Language Policy. Online: https://doi.org/10. 1007/s10993-017-9433-7.

Flores, Nelson, \& Jonathan Rosa (2015). Undoing appropriateness: Raciolinguistic ideologies and language diversity in education. Harvard Educational Review 85(2):149-71.

Ioanide, Paula (2015). The emotional politics of racism: How feelings trump facts in an era of colorblindness. Stanford, CA: Stanford University Press.

Labov, William (1982). Objectivity and commitment in linguistic science: The case of the Black English trial in Ann Arbor. Language in Society 11(2):165-201.

Leonardo, Zeus, \& Michalinos Zembylas (2013). Whiteness as technology of affect: Implications for educational praxis. Equity and Excellence in Education 46(1):150-65.

Lipsitz, George (1998). The possessive investment in whiteness: How white people profit from identity politics. Philadelphia, PA: Temple University Press.

Rosa, Jonathan, \& Nelson Flores (2017). Unsettling race and language: Toward a raciolinguistic perspective. Language in Society 46(5):621-47. 
Smitherman, Geneva (2004). Language and African Americans: Movin on up a lil higher. Journal of English Linguistics 32(3):186-96.

(Received 08 November 2017)

Address for correspondence:

Mary Bucholtz

Department of Linguistics

3432 South Hall

University of California, Santa Barbara

Santa Barbara, CA 93106-3100, USA

bucholtz@ucsb.edu

\title{
Error correction and social transformation in Creole studies and among Creole speakers: The case of Haiti
}

\author{
M I C HE L D e G R A F F \\ Massachusetts Institute of Technology, USA
}

FROM 'ERROR CORRECTION' TO 'CR ITICA L

R E F L E X I V I T Y,

Mark Lewis asks that socially engaged linguists go beyond Labov's (1982) principle of error correction (PEC) so that we can enlist critical race theory (CRT) to address 'more difficult and fundamental questions of the sociohistorical conditions of a representation of language, challenging its premises and showing its connections to racial, economic, or other forms of violence' (Lewis, this issue, p. 341). The ultimate goal is the actual TRANSFORMATION of the socioeconomic structures responsible for structural violence against speakers of stigmatized languages.

Though heartening, the article fails to acknowledge a long tradition of scholar activists, including Frantz Fanon, Paulo Freire, Pierre Bourdieu, and Michel Foucault, whose work has directly aimed toward 'actual transformation' through understanding of 'power/knowledge' systems (à la Foucault) that often include race, class, ethnicity, gender, sexuality, and other variables underlying various sorts of domination.

Lewis' call for 'critical reflexivity' implicitly echoes my own plea, in this very journal, that 'reflexive creolistics' can help transform the material conditions of Creole speakers: 